\title{
Synthesis of Nanocrystalline Copper Ferrite film by Electrochemical Technique for Toxic Gas Sensing, Li Ion Batteries and Medical Applications
}

\author{
E M Elsayed ${ }^{1}$, M M Rashad ${ }^{1}$, M R Hussein ${ }^{2}$, M M B El-Sabbah² and I A Ibrahim ${ }^{1}$ \\ ${ }^{1}$ Central Metallurgical Research and Development Institute (CMRDI), P.O. BOX.87 Helwan, Egypt11421 \\ ${ }^{2}$ Chemistry Department Faculty of Science, Al-Azhar University, Nasr City, Egypt \\ elsayed2021@gmail.com
}

\begin{abstract}
Nanocrystalline spinel copper ferrite $\mathrm{CuFe}_{2} \mathrm{O}_{4}$ thin film has been studied and synthesized via the electrodeposition-anodization process. Electrodeposited $\mathrm{CuFe}_{2}$ alloys were obtained from aqueous sulphate bath. The formed alloys were electro oxidized (anodized) in aqueous $(1 \mathrm{M} \mathrm{KOH})$ solution, at room temperature, to the corresponding hydroxides. The anodized $\mathrm{CuFe}_{2}$ alloy films were annealed in air at $400{ }^{\circ} \mathrm{C}$ for $2 \mathrm{~h}$. The parameters controlling of the electrodeposition of $\mathrm{CuFe}_{2}$ alloys such as the bath temperature, agitation and the current density were studied and optimized. The crystal structure, crystallite size and microstructure of the produced ferrites were investigated using $X$-ray diffraction (XRD), Fourier transform infra red (FT-IR) and scanning electron microscopy (SEM). XRD shows that $\mathrm{CuFe}_{2} \mathrm{O}_{4}$ had a spinel structure and the crystallite size of $\mathrm{CuFe}_{2} \mathrm{O}_{4}$ phase was $\sim 2 \mathrm{~nm}$. SEM micrograph of the formed ferrite particles shows agglomeration structure morphology with a narrow distribution of the particles.
\end{abstract}

Keywords - Copper ferrite; Electrodeposition; Thin film; Cyclic voltammetry; Nanoparticles.

\section{INTRODUCTION}

Polycrystalline metal iron oxide (ferrites) having the general formula $\mathrm{MFe}_{2} \mathrm{O}_{4}$, where $\mathrm{M}$ is divalent metal ion such as $\mathrm{Mg}, \mathrm{Mn}, \mathrm{Zn}, \mathrm{Ni}, \mathrm{Co}, \mathrm{Cu}, \mathrm{Cd}$ and $\mathrm{Fe}$ have wide ranging applications in various technical fields [1]. Owing to their important electrical and magnetic properties, metal iron oxides are used in electronics industries [2].

Most of the transition metal oxides (MO) can react with $\mathrm{Fe}_{2} \mathrm{O}_{3}$ to form the corresponding ferrites. These ferrites have the general formula $\mathrm{MFe}_{2} \mathrm{O}_{4}$, where $\mathrm{M}$ represents a divalent metal ion, such as copper which has many applications in various technical fields [3]. Ferrite has been demonstrated to be good materials for gas sensing applications [4-6].
Pulsed laser deposition techniques [7-9], dip coating [10], sputtering [11], laser ablation [12], vacuum arc evaporation [13] and the sol-gel method [14] have been used to synthesis mixed iron-oxide thin films. To obtain crystallization, these techniques require heating the substrate for several hundred degrees Celsius. Accordingly, the used substrate should have high heat resistance and a high thermal expansion coefficient that can prevent the deposited materials from degeneration, after high-temperature exposure. Also, all these techniques are expensive and the resultant film particles are rather large and nonuniform in size. Moreover, non-reproducible products and toxic gases are produced during sintering [15]. To overcome the difficulties arising from the above mentioned techniques, the electrochemical deposition method has attracted much attention because the electrochemical formation of oxide films is economical and suitable for large-scale applications [16-17]. Electricity accomplishes the oxidation and reduction, so that there are no by-product species [16]. The method has low processing temperature and its raw materials or equipment have low costs. The film composition and morphology can be controlled by controlling the electrochemical parameters. It is ability to deposit a film on a complex surface. This method is the easiest, non-vacuum method for preparing large area electrodes. Homogeneous, fine and reproducible nanocrystalline films can also be obtained [18-20].

Copper ferrite is one of the important spinel ferrites $\mathrm{MFe}_{2} \mathrm{O}_{4}$ because it exhibits phase transitions, changes semiconducting properties, shows electrical switching and variation when treated under different conditions in addition to interesting magnetic and electrical properties with chemical and thermal stabilities. Meanwhile it is used in the wide range of applications in gas sensing, catalytic applications, Li ion batteries, high density magneto-optic recording devices, color imaging and bio-processing [21-25]. 
The present study aims to prepare nanocrystalline $\mathrm{CuFe}_{2} \mathrm{O}_{4}$ thin film using the aqueous electrochemical deposition method. The effect of synthesis conditions such as agitation, temperature, current density, and deposition voltage on the properties of ferrite film was investigated. The electrochemical properties were examined using cyclic voltammetry, choronoamperometric and chronopotentiometeric techniques. The crystal structure, crystallite size and microstructure of the produced ferrite films were investigated by $\mathrm{x}$ ray diffraction (XRD) and scanning electron microscope (SEM).

\section{EXPERIMENTAL}

\section{A. Materials}

Analytical grade ammonium ferrous sulphate (Fe $\left.\left(\mathrm{NH}_{4}\right)_{2} \quad\left(\mathrm{SO}_{4}\right)_{2 .} 6 \quad \mathrm{H}_{2} \mathrm{O}\right)$, copper sulphate $\left(\mathrm{CuSO}_{4} \cdot 5\right.$ $\mathrm{H}_{2} \mathrm{O}$ ) and potassium hydroxide $(\mathrm{KOH})$ were used as starting materials. Electrodeposition experiments were carried out using freshly prepared solutions. The electrolyte was kept unstirred.

\section{B. The cell}

The experimental set-up is shown in Fig.1. A standard three-electrode cell $\left(40 \mathrm{~cm}^{3}\right)$ with a Pt plate $\left(1 \mathrm{~cm}^{2}\right)$ was used as working electrode, $\left(1 \mathrm{~cm}^{2}\right)$ as counter electrode and silver/silver chloride saturated in $\mathrm{KCl}(\mathrm{Ag} / \mathrm{AgClsat})$ as reference electrode. The working and the counter electrodes were mounted parallel to each other at a distance of $0.5 \mathrm{~cm}$.

Electrocodeposition of copper iron alloy: Experiments of electrodeposition were executed using a potentiostate-galvanostate $(25 \mathrm{~V} / 3 \mathrm{~A})$ in a galvanostatic mode. Just before deposition, the working electrode was anodically cleaned for $60 \mathrm{~s}$ at a current density of $0.01 \mathrm{~A} \mathrm{~cm}^{-2}$ in a bath similar to that used for alloy deposition.

In a second step, the deposited copper iron alloy film was anodized in $1 \mathrm{M} \mathrm{KOH}$ where the alloy film acts as anode and the counter Pt- electrode acts as cathode. The resulting film was rinsed thoroughly with distilled water and dried under vacuum in desiccators for at least $2 \mathrm{~h}$.

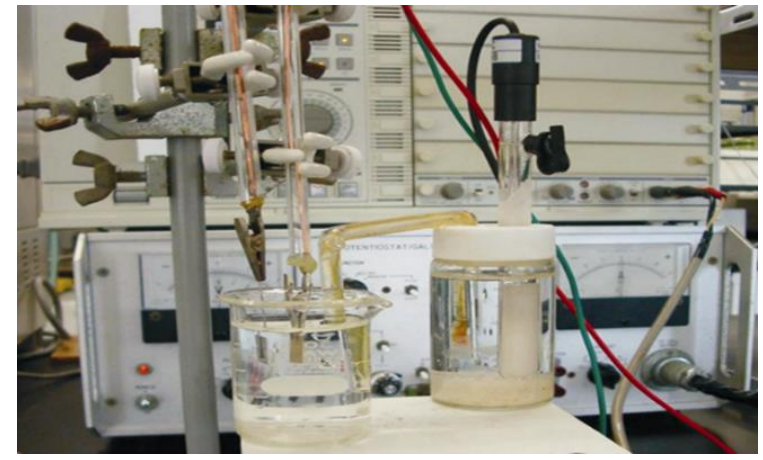

Fig.1. Experimental set-up.

Cyclic voltammetric (CV) tests were performed at room temperature using a conventional threeelectrode cell, in which pt was used as working electrode and auxiliary electrode of area $1 \mathrm{~cm}^{2}$. The reference electrode used was a saturated silver/silver chloride electrode $(\mathrm{Ag} / \mathrm{AgClsat}), \mathrm{EO}=0.200 \mathrm{mV}$ vs. standard hydrogen electrode (SHE) reference electrode. The deposition potentials were determined from the polarization curves. Cyclic voltammograms were performed with a computer-controlled potentiostate (Volta-lab 21) PGP 201 potentiostate, galvanostate $20 \mathrm{~V}, 1 \mathrm{~A}$ with general generator.

Electrodeposition was identified galvanostatically using constant currents ranging from $-20 \mathrm{~mA}$ to -100 $\mathrm{mA}$. Apparent current densities were obtained by dividing the applied current by macroscopic surface area of the deposit. The deposition conditions were optimized to get good quality of $\mathrm{CuFe}_{2}$ alloy films with maximum thickness.

The alloy films were anodized using aqueous $1 \mathrm{M}$ $\mathrm{KOH}$. The anodization current density and time were optimized to get well-adhered oxide films to the substrates. After anodization, the films were washed with distilled water and annealed after drying.

The crystalline phases in the different annealed ferrite samples were investigated using $\mathrm{X}$-ray diffraction (XRD) on a Brucker axis D8 diffractometer using the $\mathrm{Cu}-\mathrm{Ka}\left(\lambda=1.5406 \mathrm{~A}^{\circ}\right)$ radiation and secondary monochromator in the range $2 \theta$ from $20^{\circ}$ to $80^{\circ}$. Fourier transform infrared spectrosopy (FTIR) was conducted on a Thermo Electron Magna 760. The ferrite particle morphologies were examined by Field Emmission Scanning Electron Microscope and Scanning Electron Microscope (SEM) (JEOL-model JSM-5410). The crystallite size was calculated automatically by the $\mathrm{X}$-ray diffractometer. 


\section{RESULTS AND DISCUSSION}

\section{A. Cyclic Voltammetry (CV).}

Fig.2(a-c) showed the cyclic voltammogram (CV) of $0.05 \mathrm{M}$ of $\mathrm{CuSO}_{4}, 0.1 \mathrm{M} \mathrm{Fe}\left(\mathrm{NH}_{4}\right)_{2}\left(\mathrm{SO}_{4}\right)_{2}$ and $\mathrm{CuFe}_{2}$ alloy, respectively, from aqueous sulfate bath. Voltammetric studies were performed within the range of 0 to $-2 \mathrm{~V}$ using a scan rate (S.R.) of 10 $\mathrm{mVs}^{-1}$. The CV of $0.05 \mathrm{M}$ of $\mathrm{CuSO}^{4}$ is represented by one cathodic peak (C) at potential $-1.3 \mathrm{~V}$. This cathodic peak is associated with the deposition of $\mathrm{Cu}^{+2}$ ions to metallic copper equation (1). However, on reversing scan in positive direction at potential -2 $\mathrm{V}$, an anodic peak was obviously exhibited around $0.1 \mathrm{~V}$. This anodic peak relates to the dissolution of Cu metal into its ions as ascribed in equation (2).

$\mathrm{Cu}^{2+}+2 \mathrm{e}^{-} \rightarrow \mathrm{Cu}$

$\mathrm{Cu} \rightarrow 2 \mathrm{e}^{-}+\mathrm{Cu}^{2+}$

Fig.2 (b) depicts the $\mathrm{CV}$ of $0.1 \mathrm{M}$ of $\mathrm{Fe}\left(\mathrm{NH}_{4}\right)_{2}\left(\mathrm{SO}_{4}\right)_{2}$. Iron electrodeposition was started at potential $-1.2 \mathrm{~V}$ for non-stirred solution. Thus, this peak was corresponded to the electrodeposition of iron. This iron deposition process was reported to be sensitive to mass transfer. However, on reversing scan in positive direction at $-2 \mathrm{~V}$, an anodic peak appeared around $-0.1 \mathrm{~V}$. This anodic peak deduced the dissolution of iron metal into its ions.

Fig.(2c) represents the cyclic voltammograms for electrodeposition of $\mathrm{CuFe}_{2}$ alloy. It can be seen that one cathodic peak and one anodic peak were observed for $\mathrm{CuFe}_{2}$ alloy. The first cathodic peak (C1) was detected at potential $-1.4 \mathrm{~V}$ for non-agitated solution. This peak belongs to the co-deposition of $\mathrm{CuFe}_{2}$ alloy. However, on reversing scan in positive direction at $-2 \mathrm{~V}$, an anodic peak (A1) appeared around $-0.03 \mathrm{~V}$. This peak was due to the dissolution of the deposited alloy.

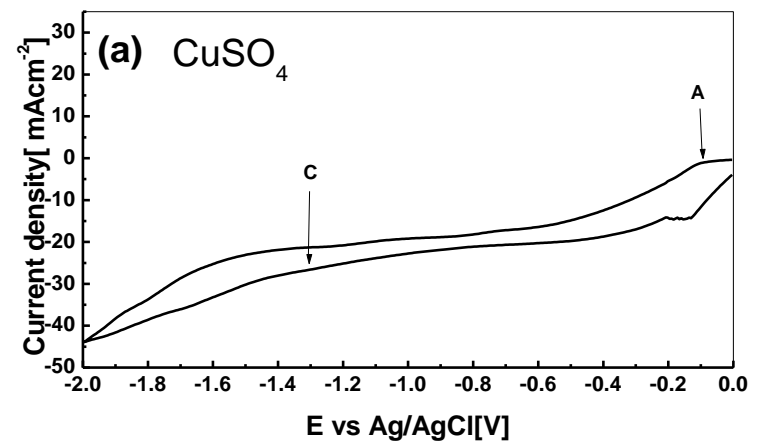

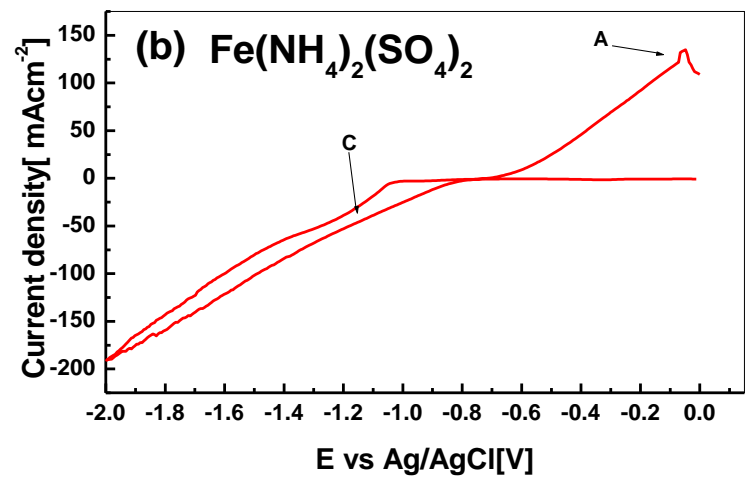

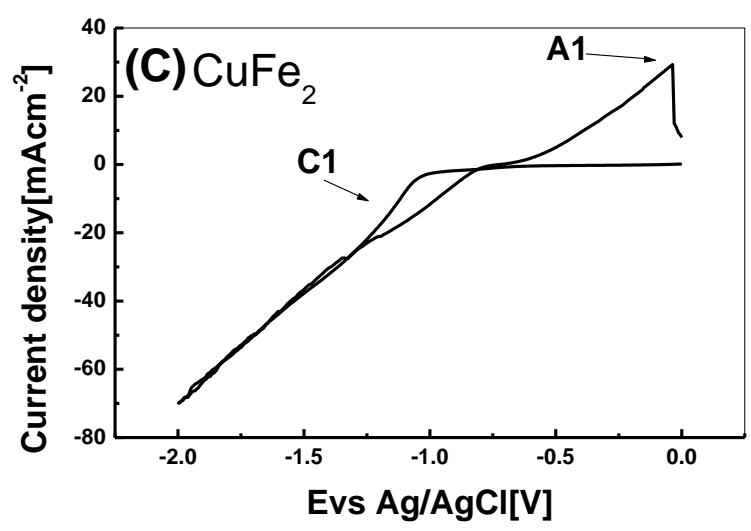

Fig.2. Voltammograms obtained on Pt electrode in different aqueous solution using scan rate $10 \mathrm{mV} / \mathrm{S}$. (a): $0.05 \mathrm{M} \mathrm{CuSO}_{4}$.

(b): $0.1 \mathrm{M}\left(\mathrm{NH}_{4}\right)_{2} \mathrm{Fe}\left(\mathrm{SO}_{4}\right)_{2}$. (c): $\mathrm{CuFe}_{2}$ alloy deposited from solution of $0.1 \mathrm{M} \mathrm{Fe}\left(\mathrm{NH}_{4}\right)_{2}\left(\mathrm{SO}_{4}\right)_{2}+0.05 \mathrm{M} \mathrm{CuSO}_{4}$.

\section{Influence of bath Agitation}

Fig. (3a) represents the cyclic voltammetric curves for electrodeposition of $\mathrm{CuFe}_{2}$ alloy on $\mathrm{Pt}$ substrate at different agitation rates. This figure is characterized by three cathodic peaks and three anodic peaks. The first cathodic peak $\left(C_{1}\right)$ appeared at potential $E=-1.4$ $\mathrm{V}$ at non agitated solution. Agitating the solution up to $500 \mathrm{rpm}$ shifted the cathodic potential to more negative potential and the potential shifted from -1.4 $\mathrm{V}\left(\mathrm{C}_{1}\right)$ for non-agitated solution to $-1.58 \mathrm{~V}\left(\mathrm{C}_{2}\right)$. Also the potential shifted from $-1.4 \mathrm{~V}\left(\mathrm{C}_{2}\right)$ to $-1.7 \mathrm{~V}(\mathrm{C} 3)$ for agitated at $1000 \mathrm{rpm}$. Moreover, agitating the solution changed the solution cathodic current density from 70 to $-120 \mathrm{~mA} / \mathrm{cm}^{2}$. Increasing the solution agitation rate reduces the thickness of the adjacent cathodic layer, which in turn shortens the diffusion path of metal deposition [26-27]. However, on reversing scan in positive direction at $-2 \mathrm{~V}$, anodic peaks (A1, $A 2$, and A3) appeared around. The anodic peak was due to the dissolution of the deposited alloy. 


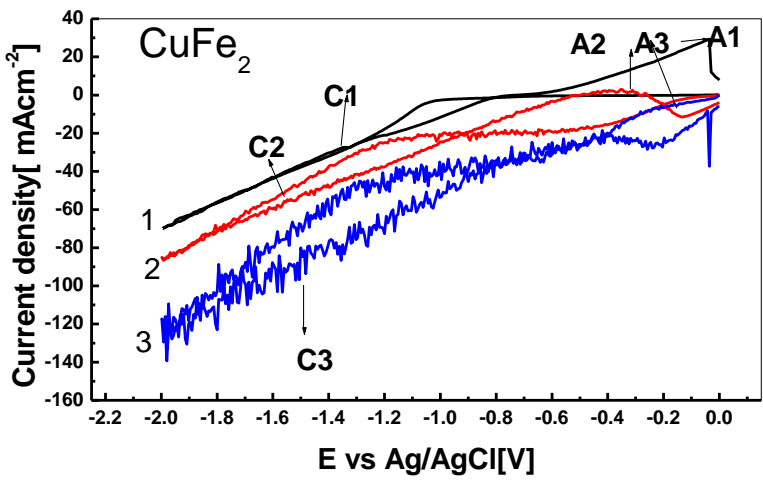

Fig.3a. Voltammograms of $\mathrm{CuFe}_{2}$ alloy deposited in $0.1 \mathrm{M} \mathrm{Fe}$ $\left(\mathrm{NH}_{4}\right)_{2}\left(\mathrm{SO}_{4}\right)_{2}+0.05 \mathrm{M} \mathrm{CuSO} \mathrm{S}_{4}$ solution at different agitation rates. (1): $0 \mathrm{rpm}$. (2): $500 \mathrm{rpm}$. (3): $1000 \mathrm{rpm}$. Scan rate $10 \mathrm{mV} \mathrm{s}^{-1}$.

\section{B. linear sweep voltammetry}

1. Influence of operating temperature

Fig. (3b) describes the linear sweep voltammetric curves (LSV) for electrodeposition of $\mathrm{CuFe}_{2}$ alloy on Pt substrate at different bath temperatures. It is seen that the increasing bath temperature from 25 to $40^{\circ} \mathrm{C}$ has subsequently formed a decrease in $\mathrm{CuFe}_{2}$ deposition potential from $E=-1.58 \mathrm{~V}$, (peak $\mathrm{C}_{1}$ ) to $\mathrm{E}$ $=-1.32 \mathrm{~V}$, (peak $\mathrm{C}_{2}$ ). Indeed, increasing bath temperature from 40 to $60{ }^{\circ} \mathrm{C}$ resulted into a decrease in $\mathrm{CuFe}_{2}$ deposition potential from $\mathrm{E}=-1.32$ $\mathrm{V}$, (peak $\mathrm{C}_{2}$ ) to $\mathrm{E}=-1.1 \mathrm{~V}$, (peak $\mathrm{C}_{3}$ ). The deposited films at room temperature were more adherent, homogeneous and coherent.

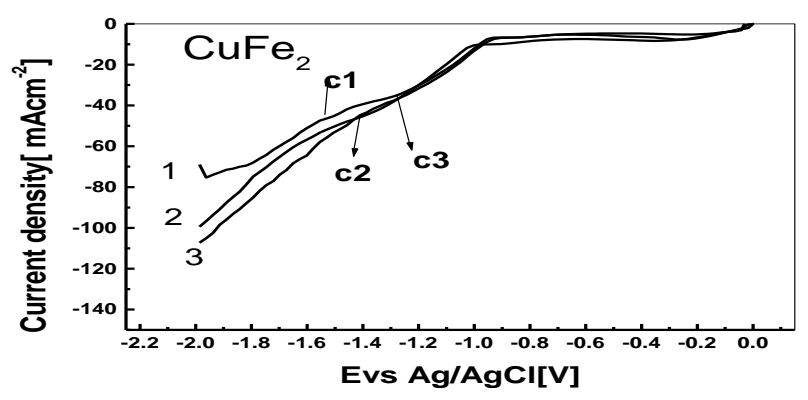

Fig.3b. Linear sweep voltammetric curves of $\mathrm{CuFe}_{2}$ alloy deposited in $0.1 \mathrm{M} \mathrm{Fe}\left(\mathrm{NH}_{4}\right)_{2}\left(\mathrm{SO}_{4}\right)_{2}+0.05 \mathrm{M} \mathrm{CuSO}_{4}$ solution at different temperatures. (1): $25^{\circ} \mathrm{C}$. (2): $40^{\circ} \mathrm{C}$. (3): $60^{\circ} \mathrm{C}$. Scan rate $10 \mathrm{mV} \mathrm{s}^{-1}$.

Generally, the raise in bath temperature increases the grain size of the deposited materials and consequently a decrease in deposition potential at a higher temperature was observed. Additionally, the increment of bath temperature enhances the rate of diffusion and ionic motilities which enhances the conductivity of deposition bath. The decrease in deposition potential with increasing temperature might be due to the increase in the content of more noble metal in the deposited alloy [28].

\section{Chronopotentimetric study}

Fig.(4) demonstrates the chronopotentiometric (galvanostatic) curves for electrodepositon of $\mathrm{CuFe}_{2}$ alloy films from the solution of $0.05 \mathrm{M} \mathrm{CuSO}_{4}+0.1 \mathrm{M}$ $\mathrm{Fe}\left(\mathrm{NH}_{4}\right)_{2}\left(\mathrm{SO}_{4}\right)_{2}$. In order to find out the suitable current for deposition, the depositions at different current values i.e., $-20,-30,-40,-50,-60$ and -100 $\mathrm{mA} / \mathrm{cm}^{-2}$ was performed respectively.

The deposition rate at these currents was found out. During the deposition, the potential first increases to a certain extent and then it decreases very fast up to a steady state value. The fast decrease in potential indicates the faster coverage of electrode surface by layer while the steady state indicates that the coverage of electrode surface is nearly complete. The value of deposition rate at $-100 \mathrm{~mA} / \mathrm{cm}^{-2}$ was observed maximum with high film thickness, thus cathodic current density of $-100 \mathrm{~mA} / \mathrm{cm}^{-2}$ was found to be suitable for the deposition of thin films.

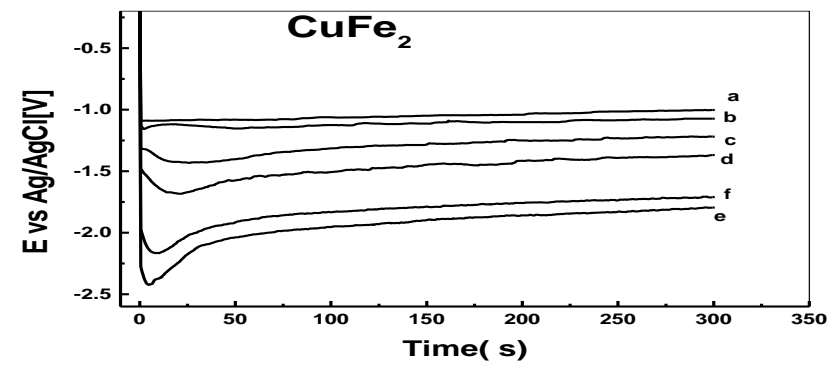

Fig.4. Chronopotentiometric curves recorded at various current densities in aqueous solution of $\mathrm{CuFe}_{2}$ alloy deposited from solution of $\left.0.1 \mathrm{M} \mathrm{Fe}\left(\mathrm{NH}_{4}\right)_{2}\left(\mathrm{SO}_{4}\right)_{2}+0.05 \mathrm{M} \mathrm{CuSO}_{4}\right)$. (a): -20 $m A c m^{-2}$. (b): $-30 m A c m^{-2}$. (c): $-40 \mathrm{mAcm}^{-2}$. (d): $-50 \mathrm{mAcm}^{-2}$. (f): $-60 \mathrm{mAcm}^{-2}$. (e): $-100 \mathrm{mAcm}^{-2}$.

\section{Chronoamperometric study.}

Fig.(5) deduces the chronopotentiometric (potentiometric) curves recorded with $\mathrm{Pt}$ substrate in the deposition solution of $0.05 \mathrm{M} \mathrm{CuSO}_{4}+0.1 \mathrm{M} \mathrm{Fe}$ $\left(\mathrm{NH}_{4}\right)_{2} \quad\left(\mathrm{SO}_{4}\right)_{2}$. In order to find out the suitable potential for deposition, the depositions at different potential values i.e., $-0.9 \mathrm{~V},-1,-1.1,-1.2,-1.3$ and $1.4 \mathrm{~V}$ were performed respectively. The deposition rate at these potentials was found out. The value of deposition rate at $-1.2 \mathrm{~V}$ has observed maximum deposition with high film thickness. It increases to a certain extent and then it decreases very fast up to a 
steady state value. The fast decrease in potentials shows that the coverage of electrode surface becomes fast. Thus, potential $-1.2 \mathrm{~V}$ was found suitable for the deposition of thin films. During the deposition, the first current during the steady state indicates that the coverage of electrode surface is nearly complete.

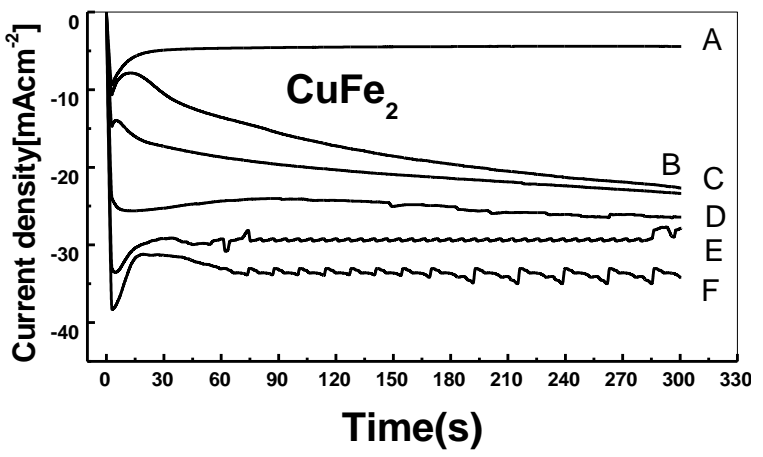

Fig.5. Variation of current density with time at constant potentials for $\mathrm{CuFe}$ deposited from solution of $0.1 \mathrm{M} \mathrm{Fe}\left(\mathrm{NH}_{4}\right)_{2}$ $\left(\mathrm{SO}_{4}\right)_{2}+0.05 \mathrm{M} \mathrm{CuSO}_{4}$. (a): -0.9 Volt. (b): -1 Volt. (c):-1. 1 Volt. (d): -1.2 Volt. (e): -1.3 Volt. (f): -1.4 Volt.

Scharifker and Hills suggested model to describe the nucleation process during initial few seconds using chronoamperometric technique. The nucleation process may be either progressive or instantaneous. Progressive nucleation corresponds to slow growth of nuclei on a less number of active sites; all of these sites are activated at the same time. Instantaneous nucleation corresponds to fast growth of nuclei on many active sites on the cathode.The effect of deposition potential on nucleation of alloy during initial time ( $\mathrm{S}-\mathrm{H}$ model) is shown in Fig. 6 (a-b).

The transients have been analyzed by comparing the chronoamperometric curves to the dimensionless theoretical curves for the diffusioncontrolled nucleation and growth of crystals in three dimensions (3D) proposed by Saba et al [20] and Kim et al [29]

The expressions for the instantaneous and progressive nucleation are given by the following equations, respectively $[28,30]$ :

$\mathrm{I}^{2} / \mathrm{i}^{2} \max =1.9542\left[\mathrm{t}_{\max } / \mathrm{t}\right]\left\{1-\exp \left[-1.2564 \mathrm{t} / \mathrm{t}_{\max }\right\}^{2} \quad\right.$ (3)

$\mathrm{I}^{2} / \mathrm{i}^{2} \max =1.2254\left[\mathrm{t}_{\max } / \mathrm{t}\right]\left\{1-\exp \left[-2.3367\left(\mathrm{t} / \mathrm{t}_{\max }\right)^{2}\right\}^{2}(4)\right.$

Where $i_{\max }$ and $t_{\max }$ are the maximum current density observed at the maximum time tmax.
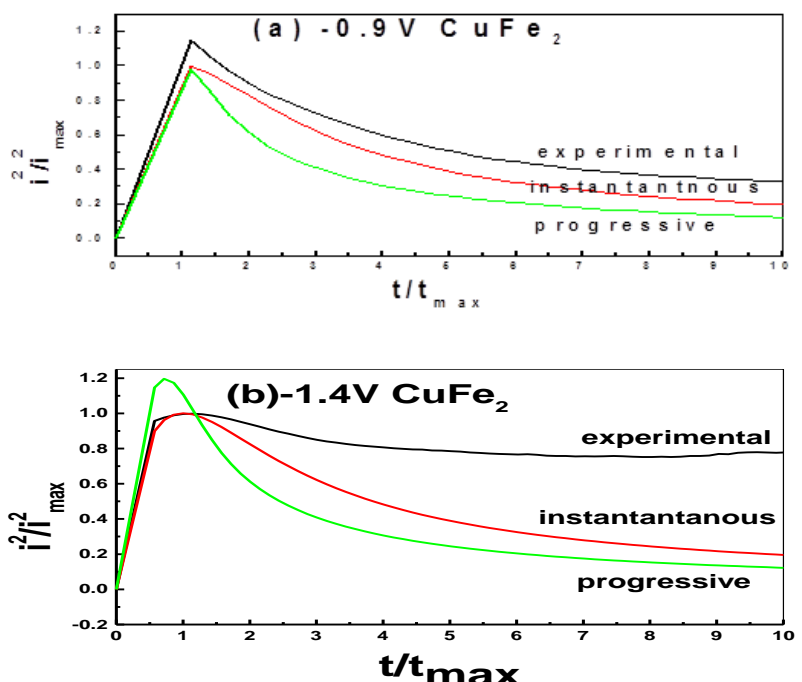

Fig.6. Nondimensional $\mathrm{i}^{2} / \mathrm{i}^{2}{ }_{\text {max }} \mathrm{vs} \mathrm{t} / \mathrm{t}_{\max }$ plots for electrodeposited $\mathrm{CuFe}_{2}$ alloy at different potentials. (A): -0.9 Volt. (B): -1.4 Volt.

\section{E. Film thickness measurements of $\mathrm{CuFe}_{2}$ alloy}

$\mathrm{CuFe}_{2}$ alloy film thickness was determined by the method of gravimetric weight difference in which area and weight of the film was measured, before and after alloy deposition [31-32].

The samples were precisely weighed; the difference of two masses gives the mass of the alloy film. The thickness was obtained by assuming density of bulk $\mathrm{MFe}_{2}$ expressed as:

$T=$ mass difference $/ \rho A$

$\rho=\rho_{1} x_{1}+\rho_{2} x_{2}$

Where $\rho_{1}, \rho_{2}$ and $x_{1}, x_{2}$ are densities and atomic fractions of $\mathrm{M}$ and Fe elements in alloy, respectively.

Fig.7 offers a plot of $\mathrm{CuFe}_{2}$ film thickness against current density. The thickness of the $\mathrm{CuFe}_{2}$ film increased $(6700 \mathrm{~nm})$ with increasing deposition current density up to $-100 \mathrm{mAcm}^{-2}$. With further increase in deposition time, film thickness was decreased. This is attributed to the formation of porous, foggy, less adherent film and/or the film may have tensile stress that tends to cause delimitation, when it becomes thick [31]. 


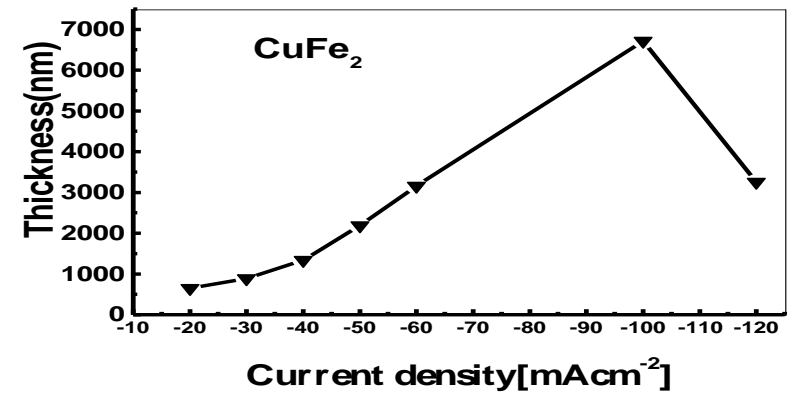

Fig.7. Variation of film thickness with current density $\mathrm{CuFe}_{2}$ alloy deposited from solution of $0.1 \mathrm{M} \mathrm{Fe}\left(\mathrm{NH}_{4}\right)_{2}\left(\mathrm{SO}_{4}\right)_{2}+0.05 \mathrm{M}$ $\mathrm{CuSO}_{4}$.

The relation between film thickness and deposition potential is shown in Fig.8. The variation of film thickness with deposition potential is observed. Initially as deposition potential increases, film thickness increases, attains maximum value $3030 \mathrm{~nm}$ for $-1.2 \mathrm{~V}$ deposition potential of $\mathrm{CuFe}_{2}$, further increase in deposition potential leads the film peelings off from the substrate due to porous, foggy and less adherent film formation.

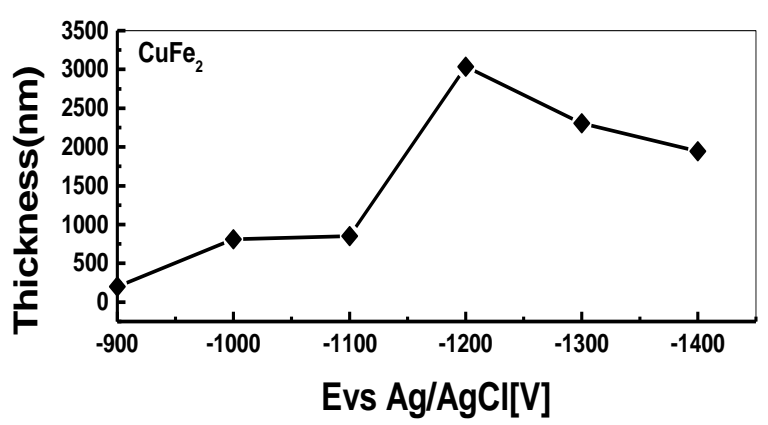

Fig.8. Variation of film thickness with potential for $\mathrm{CuFe}_{2}$ alloy deposited from solution of $0.1 \mathrm{M} \mathrm{Fe}\left(\mathrm{NH}_{4}\right)_{2}\left(\mathrm{SO}_{4}\right)_{2}+0.05 \mathrm{M}$ $\mathrm{CuSO}_{4}$.

\section{F. Current efficiency of study of $\mathrm{CuFe}_{2}$ alloy}

Current efficiency was calculated by dividing the mass of the film actually deposited on the electrode by the mass expected to be deposited in accordance with Faraday's law.

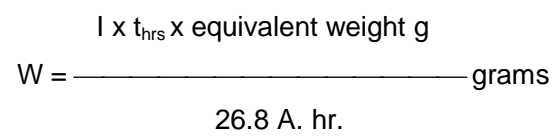

Where:

I :Current intensity in Ampers

If is the $\bar{w}$ weight of metal actually deposited at the cathode, then,

Current efficiency $=\bar{w} / \mathrm{w} * 100$
The plot of current efficiency of $\mathrm{CuFe}_{2}$ alloy deposition against various current densities of $5 \mathrm{~min}$ deposition at room temperature is shown in Fig.9. Current efficiency increases with increasing current density and afterwards decreases with further increase in current density. At $-100 \mathrm{mAcm}^{-2}$ an efficiency of $98 \%$ was observed. The reduction rate of protons is less than the rate of metal deposition below the maximum current efficiency. Further increase in current density only leads to an increase in the rate of the reduction of water molecule. It is assumed that both single metals are reduced in two consecutive steps [33].

$\mathrm{Cu}$ (II) $+\mathrm{e}^{-} \rightarrow \mathrm{Cu}(\mathrm{I})$ ads.

$\mathrm{Cu}(\mathrm{I})$ ads $+\mathrm{e}^{-} \rightarrow \mathrm{Cu}(\mathrm{S})$

$\mathrm{Fe}(\mathrm{II}))+\mathrm{e}^{-} \rightarrow \mathrm{Fe}(\mathrm{I})$ ads.

$\mathrm{Fe}(\mathrm{I})_{\mathrm{ads}}+\mathrm{e}^{-} \rightarrow \mathrm{Fe}(\mathrm{S})$

Reduction of proton and dissociation of water molecule produces hydrogen evolution that may occur as a side reaction (equation 13-15) [34].

$\mathrm{H}^{+}+\mathrm{e}^{-} \rightarrow 1 / 2 \mathrm{H}_{2}$
$\mathrm{H}_{2} \mathrm{O}+\mathrm{e}^{-} \rightarrow 1 / 2 \mathrm{H}_{2}+\mathrm{OH}^{-}$
$\mathrm{H}_{2} \mathrm{O} \rightarrow \mathrm{H}^{+}+\mathrm{OH}^{-}$

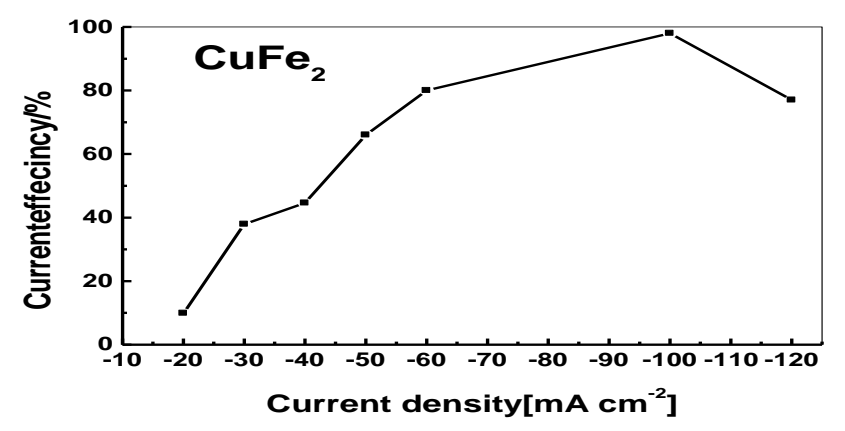

Fig .9. Variation of current efficiency with current density for CuFe $e_{2}$ alloy deposited from solution of $0.1 \mathrm{M} \mathrm{Fe}\left(\mathrm{NH}_{4}\right)_{2}\left(\mathrm{SO}_{4}\right)_{2}$ $+0.05 \mathrm{M} \mathrm{CuSO}_{4}$.

\section{G. Anodization of the Alloy}

Electrochemical oxidation of $\mathrm{CuFe}_{2}$ alloy films prepared at the optimum electrodeposition synthesis parameters was carried out at room temperature (25 ${ }^{0} \mathrm{C}$ ) according to the conditions summarized in Table 1.

The conversion of $\mathrm{MFe}_{2}$ alloy to the corresponding ferrite $\left(\mathrm{MFe}_{2} \mathrm{O}_{4}\right)$ via the hydroxide form can be explained with the following reaction

$\mathrm{MFe}_{2}+8 \mathrm{OH}^{-} \rightarrow \mathrm{MFe}_{2} \mathrm{O}_{4}+4 \mathrm{H}_{2} \mathrm{O}+8 \mathrm{e}^{-}$ 
Table 1. Conditions of the Anodization Process for the Synthesis of Copper Ferrite Thin Film.

\begin{tabular}{|c|c|}
\hline Items & Conditions \\
\hline Electrolyte & $1 \mathrm{M} \mathrm{KOH}$ \\
\hline Anodic current density & $10\left(\mathrm{~mA} / \mathrm{cm}^{-2}\right)$ \\
\hline Intercalation time & $5(\mathrm{~min})$ \\
\hline Electrolyte temperature & $25\left({ }^{\circ} \mathrm{C}\right)$ \\
\hline
\end{tabular}

After oxidation, the hydroxide films were washed with deionized water and preserved in desiccators. Then, annealing of the hydroxide converted into the corresponding oxide (ferrite) should remove some of the defects, which may be presented during the electrodeposition and anodization steps, such as voids, grain boundaries, dislocations, stresses, in homogeneity, etc. Thus, annealing is a process related to the stress relief and local structural rearrangements resulting in recovery of the alloy elements ratio of the film [20]. The formed $\mathrm{CuFe}_{2}$ hydroxide precursors were annealed at $400{ }^{\circ} \mathrm{C}$ for $2 \mathrm{~h}$.

The XRD pattern and microstructure of $\mathrm{CuFe}_{2}$ alloy prepared on gold substrate are mentioned and published previously by Elsayed and Saba [31].

\section{H. Physical characterization of $\mathrm{Cu} \mathrm{Fe}_{2} \mathrm{O}_{4}$}

\section{Crystal structure}

Fig.10 represents the XRD pattern of $\mathrm{CuFe}_{2} \mathrm{O}_{4}$ thin film; the results indicated that cubic spinel copper ferrite $\mathrm{CuFe}_{2} \mathrm{O}_{4}$ phase was observed. No extra peak related to tetragonal $\mathrm{CuF}_{2} \mathrm{O}_{4}$ was matched. The crystallite size of $\mathrm{CuFe}_{2} \mathrm{O} 4$ phase was $2 \mathrm{~nm}$.

Typical diffraction peaks of cubic $\mathrm{CuFe}_{2} \mathrm{O}_{4}$ were indexed at $2 \theta$ position of $29.8,35.51,43.2,57.4,62.8$ and 57.5 corresponding to diffraction planes of (220), (311), (400), (511), (440) and (533), respectively (JCPDS\# 00-025-0283). The strong, relatively sharp peaks of the sample demonstrate a good crystalline state of the cubic $\mathrm{CuFe}_{2} \mathrm{O}_{4}$ as formed film. The sharpness of XRD peaks has essentially attributed to the small diameter size of the $\mathrm{CuFe}_{2} \mathrm{O}_{4}$ film. From the main diffraction peaks and Scherer equation. The average size of crystallites for $\mathrm{CuFe}_{2} \mathrm{O}_{4}$ from the most intense peak (311) was based on Scherer's equation. The average crystalline size was found to be about 2 $\mathrm{nm}$ taking coefficient $\mathrm{k}=0.9$, which proves that the films are nanocrystalline. The crystallite size was calculated automatically by the $\mathrm{X}$-ray diffractometer.

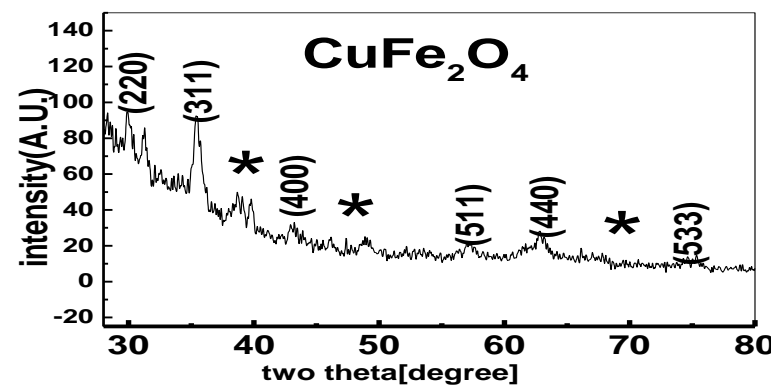

Fig.10. XRD patterns of $\mathrm{CuFe}_{2}$ alloy oxidized in $1 \mathrm{M} \mathrm{KOH}$ are followed by annealing in air at $400{ }^{\circ} \mathrm{C}$ for $2 \mathrm{~h}$, where the peaks of substrate are marked with asterisks.

Fourier transform infra red spectrum (FTIR) of sample thermally treated at $400 \quad{ }^{0} \mathrm{C}$ was recorded in the range of $400-800 \mathrm{~cm}^{-1}$ at room temperature and the obtained result is shown in Fig.11. It is known that ferrites have two common bands. The high wave number band $U_{1}$ at $540-600 \mathrm{~cm}^{-1}$ is assigned to the tetrahedral complexes, while the lower wave number $\mathrm{U}_{2}$ at $450-490 \mathrm{~cm}^{-1}$ is assigned to the octahedral complexes. Therefore, in the investigated sample, the high wave number represents the vibration of $\mathrm{Fe}^{3+-} \mathrm{O}^{2-}$ in the sub-lattice site $A$, while the lower wave number band represents the divalent metal - oxygen vibrations at the octahedral B-sites.The difference in $\mathrm{U}_{1}$ and $\mathrm{U}_{2}$ band positions is expected because of the difference in the $\mathrm{Fe}^{3+-} \mathrm{O}^{2-}$ distances for the octahedral and the tetrahedral sites. FTIR transmission spectrum revealed two dominant absorption bands at $U_{1}(560$ $\left.\mathrm{cm}^{-1}\right)$ and $\mathrm{U}_{2}\left(475^{\mathrm{cm}-1}\right)$ due to tetrahedral $\mathrm{Fe}^{3+-} \mathrm{O}^{2-}$ and octahedral site for pure copper ferrite film.

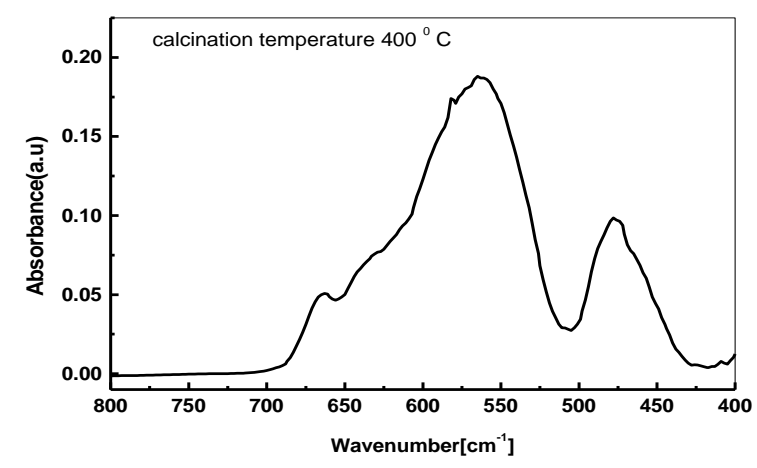

Fig.11. FT-IR spectrum of $\mathrm{CuFe}_{2}$ alloy oxidized in $1 \mathrm{M} \mathrm{KOH}$ followed by annealing in air at $400{ }^{\circ} \mathrm{C}$ for $2 \mathrm{~h}$. 


\section{Microstructure}

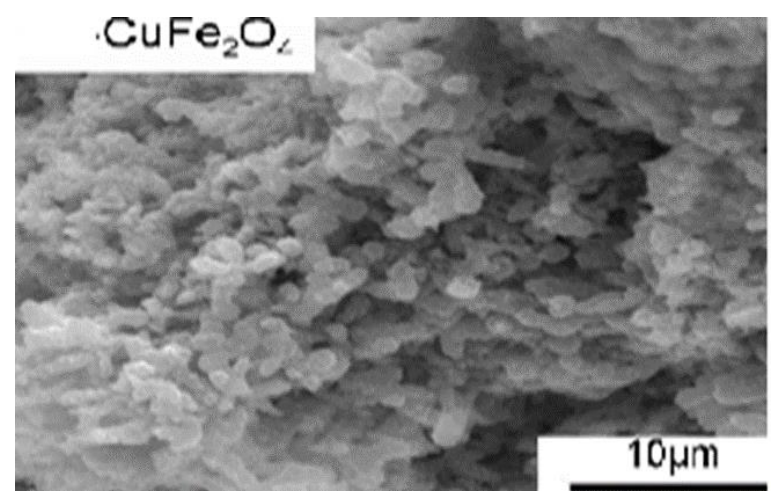

Fig.12. SEM picture of copper ferrite thin film electrodeposited from sulfate bath at current density $-100 \mathrm{mAcm}^{-2}$ deposited from solution of $0.1 \mathrm{M} \mathrm{Fe}\left(\mathrm{NH}_{4}\right)_{2}\left(\mathrm{SO}_{4}\right)_{2}+0.05 \mathrm{M} \mathrm{CuSO}_{4}$ and annealed at $400{ }^{\circ} \mathrm{C}$.

Fig.12 illustrates the SEM surface morphology of copper ferrite electrodeposited from sulphate bath at cathodic current density $100 \mathrm{~mA} \mathrm{~cm}^{-2}$. The specimens were subjected to microscopic examination at $\mathrm{X}$ 10.000. The micrograph of copper ferrite surface shows agglomeration structure morphology with a narrow distribution of the particles.

More aspects were considered for $\mathrm{CuFe}_{2} \mathrm{O}_{4}$ by Field Emmission Scanning Electron micrograph. Figure.13 depicts the formed particles that exhibited nanosphere like structure.

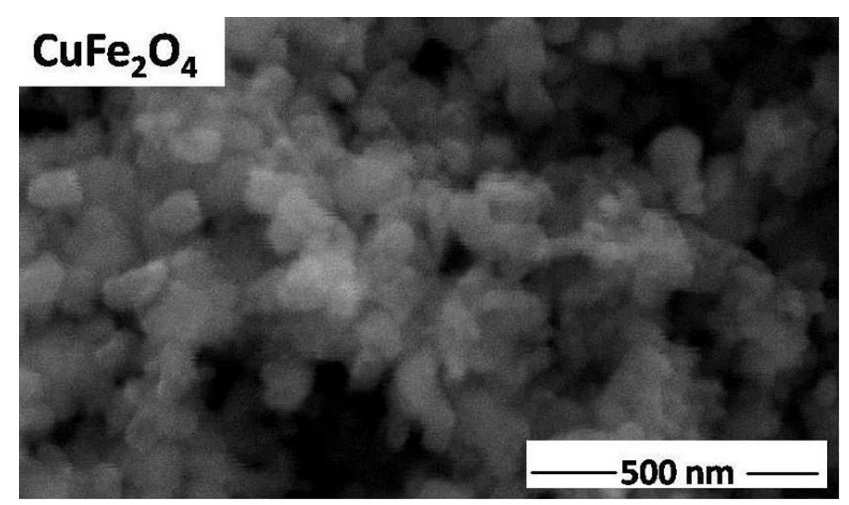

Fig.13. FE-SEM image of copper ferrite film electrodeposited at current density $-100 \mathrm{mAcm}^{-2}$ and followed by annealing in air at $400{ }^{\circ} \mathrm{C}$ for $2 \mathrm{~h}$.

\section{CONCLUSIONS}

The results can be summarized as follows:

Copper ferrite has been successfully synthesized via a novel approach of electrodeposition -anodization process.

Electrodeposited $\mathrm{CuFe}_{2}$ alloy was formed from aqueous sulphate bath at a cathodic current density $100 \mathrm{mAcm}^{-2}$ with a high current efficiency $98 \%$.
The formed alloy was anodized in $1 \mathrm{M} \mathrm{KOH}$ to form copper ferrite precursors which are annealed at 400 ${ }^{\circ} \mathrm{C}$ for $2 \mathrm{~h}$.

The results revealed that agitation effect had enhanced effect on current density, but had opposite effect on film adhesion.

The results also revealed that bath temperature had strong promoting effect on copper -iron alloy deposition.

Chronoamperometric curves showed that a higher application of constant current leads to a higher potential plateau during film deposition.

As the deposition current increases, the thickness of the deposited film increases and optimum current efficiency is reached at cathodic current density 100 $\mathrm{mA} \mathrm{cm}{ }^{2}$.

According to XR patterns the prepared film was copper ferrite with spinel crystal structure, the crystallite size was $2 \mathrm{~nm}$ predicted the film was nanocrystalline.

According to theoretical $\mathrm{SH}$ model, it is observed that the nucleation and growth mechanism prevailed experimentally instantaneous nature at lower and higher potentiostatic condition from $-0.9 \mathrm{~V}$ to $-1.4 \mathrm{~V}$.

SEM micrographs showed that compact crystallite shapes with smallest particle size and full covered surface and shows agglomeration structure morphology with a narrow distribution of the particles noted.

\section{REFERENCES}

[1] R.P. Patil, S.D. Delekar, D.R. Mane and P.P. Hankare.."Synthesis structural and magnetic properties of different metal ion substituted nanocrystallline zinc ferrite" Results in Physics, vol. 3, pp. 129, 2013.

[2] M. Maheen, K. Rafeekali, R. Sebastian and E.M. Mohammed. "Structural and Dielectric Studies of Cerium Substituted Nickel Ferrite Nano Particle" Int. J. of Eng. And Sci. (IJES), vol. 4, pp. 33, 2015. 
[3] L.B. Zakiyah, E. Saion , N.M. Al-Hada, E.G. Shahi, A. Salem, N. Soltani and S. Gene. "Upscalable synthesis of size-controlled copper ferrite nanocrystals by thermal treatment method" Materials Science in Semiconductor Processing, vol. 40, pp.564, 2015.

[4] F. Tudorache, E. Rezlescu, P.D. Popa and N. Rezlescu. "Scalar hysteresis measurement using FFT" Journal of Optoelectronics and Advanced Materials, vol. 10, pp. 2386, 2008.

[5] N.M. Deraz, and A. Alarifi, "Microstructure and Magnetic Studies of Zinc Ferrite Nano Particles" International Journal of Electrochemical Science, vol. 7, pp. 650, 2012.

[6] Y.J. Tu, C.F. You, C.K. Chang and S.L. Wang. "Adsorption behavior of As (III) onto a copper ferrite generated from printed circuit board industry", Chemical Engineering Journal, vol. 225, pp. 433, 2013.

[7] M. Satalkara, S.N. Kanea, A .Ghosha, S. Raghuvanshia, P. Tapkira, N Ghodkec, D.M. Phasec, R.J. Chaudharyc, A. Paskod, M. LoBued, and F. Mazaleyratd. "Study of hard soft magnetic ferrite films pulsed laser deposition" Journal of Physics: Conference Series, vol. 534, pp. 012043, 2014.

[8] Y. N. NuLi, Y.-Q. Chu and Q.Z. Qin, "Nanocrystalline $\mathrm{ZnFe2O} 4$ and Ag-doped $\mathrm{ZnFe2O} 4$ films used as new anode materials for Li-ion batteries" J. Electrochem Soc. Vol. 151, pp. A1077, 2004.

[9] A.T. Raghavender, N.H. Hong, K.J. Lee and J.M. Hwa. "Influence of Gd Doping on the Magnetic Properties of Copper Ferrite Thin Films Fabricated Using Pulsed Laser Deposition Technique" Advanced Science, Engineering and Medicine, vol. 6, pp. 273, 2014.

[10] G. Ruhi, O.P. Modi and I.B. Singh. "Hot Corrosion Behavior of Sol-Gel Nano Structured Zirconia Coated 9Cr1Mo Ferritic Steel in Alkali Metal Chlorides and Sulphates Deposit Systems at High Temperatures" Journal of Surface Engineered Materials and Advanced Technology, vol. 3, pp. 55, 2013.
[11]R. Sultan and M. Singh. "Thin films," Journal of Applied Physics, vol. 105, pp. 7, 2009.

[12] A. Yang, Z. Chen, S.M. Islam, C. Vittoria and V.G. Harris. "Cation engineering of Cu-ferrite films deposited by alternating target laser ablation deposition "Journal of Applied Physics, vol. 103, pp. 7, 2008.

[13]S. Kumbhar, A.D. Jagadale, N.M. Shinde and C.D. Lokhande. "Chemical synthesis of spinel cobalt ferrite (CoFe2O4) nano-flakes for supercapacitor application" Applied Surface Science, vol. 259, pp. 39, 2012.

[14]A. Sutka and G. Mezinskis "Sol-gel autocombustion synthesis of spinel-type ferrite nanomaterials" Journal of Frontiers of Materials Science, vol. 6, pp. 128, 2012.

[15] C.D. Lokhande, S.S. Kulkarni, R.S. Mane and S.H. Han."Copper ferrite thin films: single-step non-aqueous growth and properties" Journal of Crystal Growth, vol. 303, pp. 387, 2007.

[16]E.M. Elsayed, M.M. Rashad, H.F.Y. Khalil, I.A. Ibrahim, M.R. Hussein and M.M.B. El-Sabbah. "The effect of solution $\mathrm{pH}$ on the electrochemical performance of nanocrystalline metal ferrites MFe2O4 (M=Cu, Zn, and Ni) thin films" Appl Nanosci, vol. 6, pp. 485-494, 2016.

[17]S. Sartale, C.D. Lokhand and M. Muller. "Electrochemical synthesis of nanocrystalline $\mathrm{CuFe2O} 4$ thin films from non-aqueous (ethylene glycol) medium" Materials Chemistry and Physics, vol. 80, pp. 120, 2003.

[18] N.M. Deraz. "Production," Int. J. Electrochem. Sci., vol. 7, pp. 6501, 2012.

[19] S.M. Chavana, M.K. Babrekarc, S.S. Moreb and K.M. Jadhavc. "Electrochemical Synthesis of Nanocrystalline Ni0.5Zn0.5Fe2O4 Thin Film from Aqueous Sulfate Bath" Journal of Alloys and Compounds, vol. 507, pp. 21, 2010.

[20] A.E. Saba, E.M. Elsayed, M.M. Moharam, M.M. Rashad and R.M. Abou-Shahba. "Structure and magnetic properties of NixZn1-xFe2O4 thin films prepared through electrodeposition method" Journal of Materials Science, vol. 46, pp. 3574, 2011. 
[21]F. Tudorache, E. Rezlescu, P.D. Popa and N. Rezlescu. "Study of some simple ferrites as reducing gas sensors" Journal of Optoelectronics and Advanced Materials, vol. 10, pp. 1889, 2008.

[22] M.M. Rashad, R.M. Mohamed, M.A. Ibrahim, L.F.M. Ismail, E.A. Abdel-Aal. "Magnetic and catalytic properties of cubic copper ferrite nanopowders synthesized from secondary resources" Advanced Powder Technology, vol. 23, pp. 315, 2012.

[23] S. Singh, B.C. Yadav, R. Prakash, B. Bajaj and J.R. lee. "Synthesis of nanorods and mixed shaped copper ferrite and their applications as liquefied petroleum gas sensor" Applied Surface Science, vol. 257, pp. 10763, 2011.

[24] L. Jaswala and B. Singh. "Ferrite materials: A chronological review," J. Integr Sci Technol, vol. 2, pp. 69-7, 2014.

[25] O.M. Lemine. "Effect of milling conditions on the formation of $\mathrm{ZnFe2O} 4$ nanocrystalline" International Journal of Physical Sciences, vol. 8, pp. 380, 2013.

[26] T. Yoshida, D. Komatsu, N. Shimokawa and H. Minoura "Mechanism of cathodic electrodeposition of zinc oxide thin films from aqueous zinc nitrate baths" Thin Solid Films, vol. 451, pp. 166, 2004.

[27]E.M. Elsayed, A.E. Shalan, M.M. Rashad. "Preparation of $\mathrm{ZnO}$ nanoparticles using electrodeposition and co-precipitation techniques for dye-sensitized solar cells applications" Journal of Materials Science: Materials in Electronics, vol. 25, pp. 3412, 2014.
[28] S.D. Sartale and C.D. Lokhande." "Room temperature preparation of $\mathrm{NiFe} 2 \mathrm{O} 4$ thin films by electrochemical route" Indian Journal of Engineering and Materials Science, vol. 7, pp. 404, 2000.

[29] Y. Kim, J. Jung, S. Kim and W.S. Chae. "Cyclic Voltammetric and Chronoamperometric Deposition of CdS" Materials Transactions, vol. 54, pp. 1467, 2013.

[30] A.E. Saba, E.M. Elsayed, M. Moharam and M.M. Rashad. "Electrochemical Synthesis of Nanocrystalline Ni0.5Zn0.5Fe2O4 Thin Film from Aqueous Sulfate Bath" International Scholarly Research Network, vol. 2012, pp. 1-8, 2012.

[31]E.M. Elsayed and A.E. Saba. "Electrodeposition and characterization of copper iron oxide thin films from aqueous sulphate bath" Journal of Steel and Related Material, Steel Grips, vol. 7, pp. 137, 2009.

[32] E.M. Elsayed, A.Y. Shounoda and A.E. Saba. "Astudy on the electro-synthesis of zinc oxide films" Steel Grips Surface Technology, vol. 9, pp. 201, 2011.

[33] S.D. Sartale and C.D. Lokhande. "Electrochemical synthesis of nanocrystalline $\mathrm{CoFe} 2 \mathrm{O} 4$ thin films and their characterization" Ceramics International, vol. 28, pp. 467, 2002.

[34]J.L. Gunjakar, A.M. More, V.R. Shinde, C. Lokhande. "Synthesis of nanocrystalline nickel ferrite (NiFe2O4) thin films using low temperature modified chemical method" Journal of Alloys and Compounds, vol. 1, pp. 465, 2008. 